\title{
ENHANCEMENT OF ROAD SAFETY BY IMPROVING THE PROCESS OF ROAD INFRASTRUCTURE DESIGNING
}

\begin{abstract}
Characteristics of road infrastructure affect the level of road safety significantly. Therefore, the process of designing such infrastructure gains special importance. A general concept of improving road infrastructure designs has been formulated based on the analysis of causes of their low quality. The concept includes the following types of measures: educational, procedural, publishing, informative, and legal to be taken by central government authorities. Educational actions are to involve primarily the systematic training for all persons involved in the designing process. Moreover, the introduction of road safety procedures has been proposed for all road infrastructure designs as well as the preparation of study documentation, a new 'Design Consultation Card', consulting geometric solutions, and the procedures that should improve the quality of ToRs. Activities within publishing are to focus on preparing and publishing design-related studies. Informative actions include the establishment of a voivodeship road safety database including, among other, design norms and regulations, design standards, catalogues of good and bad practices, manuals, scripts, training materials, examples of ToR, and auxiliary designing materials. The last group of activities requires national regulations.
\end{abstract}

Keywords: road safety, traffic engineering, designing safe road infrastructure, and transport road safety, traffic, traffic management

\section{Introduction}

According to both foreign and domestic studies, properties of road infrastructure have a major effect on road safety. Therefore, in the process of designing a 'safe' road infrastructure, one has to keep in mind that the minimum risk of

\footnotetext{
${ }^{1}$ Autor do korespondencji/corresponding author: Tomasz Szczuraszek, University of Science and Technology, Department of Road and Transport Engineering, ul Kaliskiego 7, 85-796 Bydgoszcz, tel. (52) 340-84-30, zikwb@utp.edu.pl

${ }^{2}$ Jan Kempa, University of Science and Technology, Department of Road and Transport Engineering, janke@utp.edu.pl

${ }^{3}$ Paulina Olenkowicz-Trempała University of Science and Technology, Department of Road and Transport Engineering, paulina.olenkowicz@utp.edu.pl
} 
road incidents and their casualties should be guaranteed once an investment project is completed.

One of the principal causes of the insufficient level of road safety on Polish roads is the fact that the participation of a road as the origin of road incidents is not recognised enough. Statistics of road incidents do not include numerous defects of a road infrastructure, traffic characteristics, or traffic organization, which results from the fact that the participation of such errors as causes of road incidents is generally hard to determine. Only a detailed cause and effect analysis of road incidents gives a chance to identify such an effect of a road infrastructure.

The negative impact of road-traffic characteristics on road users may vary and involves, among other, the increased difficulty level of tasks that have to be performed by road users, low 'readability' of a road, forcing road users to change their behaviour suddenly, facilitating or provoking drivers to drive at excessive speeds, higher than a safe speed, etc.

The complexity of the cause and effect relationship between road incidents and the broadly understood road environment stems also from different influences of road-traffic characteristics on road users, the simultaneous effect of various negative properties of road and traffic on road users, and the changing effect of negative road and traffic properties on road users when combined with other characteristics.

This article is aimed at indicating the potential enhancements of road safety by improving the process of road infrastructure designing.

\section{Main Causes of Low Design Quality}

The main causes of the low quality of road infrastructure designs may be divided into three groups in terms of the institutional hierarchy of entities that influence the designing process:

- Designers: the lack of suitable knowledge and experience held by great many designers, especially in the area of traffic processes and road safety; traffic organization designs are often produced by persons holding low competences (which is allowed by the present rules of law); the frequent failure of designers to carry out analyses that provide the adequate design level in terms of road safety (including in particular: traffic forecasts, flow capacity analyses, visibility analyses, and serviceability analyses); the belief that the application of provisions included in the Technical Terms and Conditions warrants the safe solutions and the automatic compliance with regulations that concern road designing.

- It is worth stressing that the most common excuse given by designers for the low quality or errors in designs is the formalization of the design process. It is true that it is becoming more and more time consuming to obtain permits, approvals, certificates, declarations, opinions, justifications, etc. It is estimated 
that the 'actual' design work constitutes at present maximum $25 \%$ time of the whole design process.

- Investors (road administrators) who order designs and take decisions on its scope and acceptance: designers are not required to make their designs subject to a road safety audit (with some exceptions, including GDDKiA - General Director for National Roads and Motorways); only occasional requirements of study documentation in the design process (except for GDDKiA); accepting inadequate assessment, endorsing, and consultation procedures of designs among numerous road administrators; a short time of developing designs, resulting usually from the pressure put by investors and the improper road investment planning; only a sporadic requirement for endorsing road geometry solutions in designing processes in terms of the possible application of suitable traffic organization solutions; the careless and unprofessional preparation of terms of reference for numerous road investment projects; and

- Central authorities that impose in regulations, legal acts, and legislation the main framework and rules of the designing process: no regulations or procedures that necessitate the performance of road safety audits with respect to most designs; no materials that explain and justify the adopted road design rules; imperfections (ambiguities and low quality) of some design regulations and rules applicable in Poland; the content of some regulations that is not adequate to the present knowledge, in particular within road safety; no sufficient tools that enable proper designing in terms of road safety; no regulations that determine the qualifications of designers of traffic organization designs, including of street lights; imperfections of the Public Procurement Law.

The problem is illustrated with studies [1,2]. Moreover lots of main reasons for such poor quality of road infrastructure designs are illustrated with studies $[3,4,5]$.

\section{General Concept of Design Quality Improvement}

Based on the analysis of causes that influence the low quality of road infrastructure designs listed in section 2, a general concept has been formulated of improving their quality through various implementation measures, namely: education, procedural actions, publishing, an informative camping, and actions taken towards the central state authorities.

\section{- Education}

Education should focus on organising systematic training for the following groups of people: persons involved in designing, road safety auditors, officers endorsing designs, and authors of terms of reference.

In this respect, the establishment of six cycles of training has been proposed for the personnel involved in road safety in the voivodeship and the extension of the present training for rescue services. The training should involve: one-term 
studies for road safety auditors, two-term post-graduate studies in 'Road Safety' for expert road engineering personnel, one-week training in 'Road Traffic Safety Management' (dedicated mostly to poviat and gmina road safety inspectors and other poviat and gmina officers and road administrators), one-day training entitled 'Role of Local Governments in Road Safety' (dedicated to starosts, mayors, and voyts), two-day training entitled 'Road Safety Supervision and Control' (for police and Road Transport Inspectorate officers), one-week training in 'Road Traffic Safety in Area Development and Planning', aimed at extending the knowledge of road safety problems among planners, and one-day training in road rescue services with a greater frequency and with a much broader scope than at present.

It should be noted that, as explained in [6] specialist of Gdańsk and Cracow University of Technology conduct fundamental and periodical trainings for road safety auditors. Every year several dozen new road auditors are ready to work for road authorities.

\section{- Procedural measures}

The introduction of the following new procedures is planned in the design process: safety audits of all road infrastructure designs, preparing study documentation before any major design processes, a new 'Design Consultation Card', consulting geometric solutions with a road administrator, and procedures that enable the improvement of ToR quality for design tasks.

The present experience shows that the application of audit procedures gives expected positive results. It is often only the awareness of a road administrator or designer that a design will be subject to the presented procedure makes both parties dedicate much more time to selecting correct design solutions and devote more effort to provide their compliance not only with technical-operational requirements but to provide the necessary level of road safety as well. To cover all road design projects with the audit procedure in the present legal conditions, the following are necessary: adopting a resolution by the Voivodeship Road Safety Council, signing an agreement in this respect between the Council and the local government authorities, and the undertaking by road administrators to include road safety audits into provisions when issuing decisions on building terms and conditions, in terms of reference, and in contracts for work related to designs of road infrastructure.

In Poland, however in limited range, new legal acts have been introduced, which obliging road authorities to prepare road safety assessment and road safety audits for road designs [7]. It is the result of European Parliament and Council Directive, that requiring Member States to put in place and implement a necessary procedure or procedures to carry out a systematic action in road safety aspects.

According to the present practice and experience, the first stage of developing important designs of road infrastructure should be always to prepare study 
documentation, which gives numerous benefits, such as, first of all, excluding solutions that are not technically feasible, not fully safe, economically controversial, unfavourable due to environmental protection, or impossible to implement, e.g. because of social aspects. Other advantages include: the complete and good knowledge of the advantages and disadvantages of specific options (the ability to carry out a multi-criteria analysis to underlie the selection of an optimum option that takes account of conditionings: road safety, economic, social, and environmental), the estimation of costs and economic efficiency of an investment project including the sensitivity analysis, the indication of potential difficulties in implementing a project in its further phases, the establishment of solid foundations for the compliant and explicit formulation of the provisions of the Terms of Reference concerning the further phase of designing.

It is proposed to introduce the division of all road investment projects into four groups in terms of their importance and the attributed scope of study documentation: very important - the documentation should include four phases: a network study, a corridor study, a technical-economic study, and a programme concept (likewise in the case of GDDKiA documentation); important - the documentation should feature an extended conceptual design; less important - the documentation is to include a simplified conceptual design, and projects that do not require any research work.

At present, a road administrator occupies a highly privileged position in the designing phase. If a design is not accepted by a road administrator, a designer cannot submit it to a competent authority for approval; consequently, a failure to obtain a building permit or a permit for the implementation of a road investment project results in financial penalties imposed on the designer. Hence, designers agree quite often to reject their own solutions, which are favourable in terms of road safety but expensive, and use solutions imposed by road administrators, which are cheaper but do not guarantee the achievement of a desired road safety level. This situation results from the excessively discretionary nature of certain provisions in regulations that govern road designing as well as limited financial resources for implementing investment projects. Another unfavourable factor is also the lack of an entity that would be consulted on in case of differences of opinion, if any, between a road administrator and a designer as to applied design solutions. Therefore, it is proposed to improve this designing phase by the obligatory introduction by all road administrators of consultation and endorsement cards for all road infrastructure and traffic organization designs as well as the introduction of an independent entity that would give opinions on potential differences between a road administrator and a designer. A consultation and endorsement card should include comments and objections including their justification as well as opinions and assessments expressed by all entities that participate in endorsing and consulting a design. A road administrator and a designer should respond in writing to all entries included in a card. In the event of any differences of opinions as to design solutions between a road administra- 
tor and a designer, a record of divergences is to be formulated. It is proposed that an entity that gives an opinion on the record of divergences should be a person holding the qualifications of a road safety auditor, and the costs of preparing an opinion, likewise the costs of an audit, should be borne by a designer.

Unfortunately, numerous Terms of Reference (ToR) have the following weaknesses: too vague formulation, ambiguous and imprecise phrasing or giving incomplete or missing some, often very important, tasks to be performed. Such deficiencies give great interpretation potential to a contractor, which is often used 'ingeniously' by contractors. At the same time, they become a source of unnecessary conflicts between contractors and ordering parties. According to the analysis of great many ToRs, in general they do not include any road safety requirements, and if they do, they are often a very good example of how ambiguously the terms of reference may be formulated.

Tasks that are most often omitted in ToRs are the analysis of forecast traffic, flow capacity, visibility, and serviceability, which should come as a surprise, because after all the results of such analyses often underlie a selection of a specific design solution. Such situations result from the fact that, unfortunately too often, persons who prepare terms of reference and their scope (especially in case of administrators of roads of lower categories) do not have required knowledge of road designing and, most important, of road safety. Therefore, actions are proposed aimed at eliminating such deficiencies by: delegating authors of ToRs to relevant trainings and courses (such persons need to have the required knowledge in road infrastructure designing, including road safety), outsourcing ToRs (i.e. from persons with adequate skills and experience, especially in the event of large and important road infrastructure projects, which applies especially to all poviat and gmina road administrators), including examples of ToRs for different investment tasks in the voivodeship databases and the obligatory inclusion of a work timetable in ToR.

\section{- Publishing activity}

The publishing activity should focus on developing and publishing the following: relevant manuals and books, catalogues of good and bad practices, training materials, design standards, and auxiliary materials for designing.

There are not enough manuals concerning the state-of-the-art know-how in road safety on the Polish market, including in particular manuals that concern the area development and planning, safe road infrastructure designing, road management, and road traffic. Therefore, a proposal is made to prepare the following manuals: 'Road Safety Management', 'Road Safety in Area Development and Planning', and 'Road Safety - Selected Topics.

Because Polish regulations lack detailed selection criteria or rules of applying a geometric parameter and technical-operational values for numerous elements of road infrastructure, for the same external conditions different solutions are applied, many a time in the area of the same municipality. As a consequence 
of this practice, road users are often confused as to the rules of using such solutions in practice and the safe behaviour in traffic. The necessity to develop uniform design standards for many road infrastructure elements that should apply all over Poland has been discussed for years now. Unfortunately, the authorities that are competent to develop such standards are not taking any steps to change this very unfavourable situation. Therefore, many large cities in Poland have already developed or are developing such standards (usually concerning bikes) on their own. Consequently, a proposal is made that the following most important and at the same most urgent standards should be introduced: 'Cycling Path Designing and Development', 'Low Speed Zone Designing and Equipment'.

New literature about design safe road infrastructure has been increasingly published in recent years on the Polish publishing market, and good examples may be $[9,10]$.

\section{- Informative measures}

In this area, the establishment of the voivodeship database of traffic safety is planned, which will be available to all designers and will contain, among other: designing standards and regulations, catalogues of good and bad practices, manuals, scripts, training materials, examples of ToRs for selected investment activities, auxiliary materials for designing, etc.

\section{- Activities of central government authorities}

There are certain measures aimed at enhancing road traffic that cannot be implemented on a local level, because they require national regulations. Such measures include: conducting a road safety audit for all road infrastructure designs, the verification and updates of 'Technical Conditions to be Met by Public Roads and their Location', the introduction of amendments to the 'Public Procurement Law', making amendments to the legal acts that concern designs of permanent and temporary traffic organization, and the publication of missing design standards and design auxiliary materials. The solution of such problems requires voivodeship structures involved in road safety to request central government authorities for taking fast and effective measures in this respect.

\section{Literature}

[1] Collective work edited by prof. T. Szczuraszek: Diagnoza bezpieczeństwa ruchu drogowego. GAMBIT KUJAWSKO-POMORSKI (Volume I). Diamond Books. Bydgoszcz 2010.

[2] Collective work edited by prof. T. Szczuraszek: Program poprawy bezpieczeństwa ruchu drogowego. GAMBIT KUJAWSKO-POMORSKI (Volume II). Diamond Books. Bydgoszcz 2012. Drogownictwo 4/2012.

[3] Tracz M., Gaca S.: Wdrażanie audytu bezpieczeństwa ruchu drogowego w Polsce. Drogownictwo 4/2010. 
[4] Gaca S.: Rola przepisów technicznych i promocja dobrej praktyki jako środka poprawy bezpieczeństwa ruchu. Drogownictwo 4/2010.

[5] Gaca S.: Badania naukowe i ich rola w przekształcaniu sieci drogowej. Zeszyty Naukowe Politechniki Rzeszowskiej „Budownictwo i inżynieria środowiska. Zeszyt nr $59(3 / 2012 / 1)$.

[6] Rozporządzenie Ministra Transportu, Budownictwa i Gospodarki Morskiej z dnia 14 września 2012 r. w sprawie szkoleń oraz wzoru certyfikatu dla audytorów bezpieczeństwa ruchu drogowego. Dz. U. 2012r. poz. 1079.

[7] Zarządzenie nr 42 Generalnego Dyrektora Dróg Krajowych i Autostrad z dnia 3 września 2009 r. w sprawie oceny wpływu na bezpieczeństwo ruchu drogowego oraz audytu bezpieczeństwa ruchu drogowego projektów infrastruktury drogowej.

[8] Dyrektywa Parlamentu Europejskiego i Rady Nr 2008/96/WE w sprawie Zarządzania bezpieczeństwem infrastruktury drogowej. Dziennik Urzędowy Unii Europejskiej L $319 / 5$ z dnia 29.11.2008.

[9] Collective work edited by prof. K. Jamroz: Ochrona pieszych. Podręcznik dla organizatorów ruchu pieszego. Krajowa Rada BRD. Gdańsk, Kraków, Warszawa 2014.

[10]Zalewski A.: Uspokojenie ruchu jako zagadnienie urbanistyczne. Zeszyty Naukowe Politechniki Łódzkiej nr 1104. Łódź 2011.

\title{
POPRAWA BEZPIECZEŃSTWA RUCHU DROGOWEGO POPRZEZ UDOSKONALANIE PROCESU PROJEKTOWANIA INFRASTRUKTURY DROGOWEJ
}

\begin{abstract}
Streszczenie
Cechy infrastruktury drogowej mają znaczący wpływ na poziom bezpieczeństwa ruchu drogowego. $\mathrm{Z}$ tego względu szczególnego znaczenia nabiera proces projektowania tej infrastruktury. $\mathrm{Na}$ bazie analizy przyczyn wpływających na niską jakość projektów infrastruktury drogowej sformułowano ogólną koncepcję poprawy ich jakości poprzez działania: edukacyjne, proceduralne, publikacyjno-wydawnicze, informacyjne oraz o charakterze prawnym w stosunku do jednostek centralnych kraju. Działania edukacyjne polegać mają na systematycznych szkoleniach wszystkich osób biorących udział $\mathrm{w}$ procesie projektowym. Zaproponowano także wprowadzenie procedur postępowania dotyczących: audytu brd wszystkich projektów infrastruktury drogowej, wykonywania dokumentacji studialnych, nowej „Karty uzgodnień projektu", uzgadniania rozwiązań geometrycznych oraz procedur poprawiających jakość SIWZ. Działania publikacyjno-wydawnicze polegać mają na opracowaniu i wydaniu publikacji związanych z projektowaniem. Wśród działań informacyjnych zaplanowano utworzenie wojewódzkiej bazy informacji o bezpieczeństwie ruchu, zawierającej między innymi: normy i przepisy projektowania, standardy projektowania, katalogi dobrych i złych praktyk, podręczniki, skrypty, materiały szkoleniowe, przykładowe opisy SIWZ oraz materiały pomocnicze do projektowania. Ostatnia grupa działań wymaga regulacji krajowych.
\end{abstract}

Słowa kluczowe: bezpieczeństwo ruchu drogowego, inżynieria ruchu drogowego, projektowanie bezpiecznej infrastruktury drogowej, transport

Przestano do redakcji: 07.06.2016 $r$.

Przyjęto do druku: 30.06 .2016 r.

DOI: $10.7862 / \mathrm{rb} .2016 .95$ 